\title{
La arena como capa intermedia especializada para la mejora del aislamiento acústico entre recintos superpuestos
}

\section{Dry sand as a specialized layer to improve the acoustic insulation between rooms one above another}

\author{
C. Díaz (*); D. Caballol*), A. Díaz(*), A. Rodríguez(*)
}

Recepción / Received: 15-VI-12

Aceptación / Accepted: 8-X-12

Publicado online / Online publishing: 24-X-12

\section{RESUMEN}

En este trabajo se exponen y se analizan los resultados experimentales in situ del aislamiento acústico a ruido aéreo y a ruido de impactos de elementos de separación horizontales, habituales hace años, en los que sobre el forjado se coloca una capa uniforme de arena que sirve de asiento al suelo cerámico.

Los resultados de las mediciones acústicas muestran que, cuando en el elemento de separación horizontal entre los recintos hay una capa intermedia de arena, el aislamiento acústico es mejor que el que se obtendría con otros sistemas constructivos de igual masa por unidad de superficie, con el suelo unido rígidamente al forjado. El efecto de la capa de arena colocada entre el forjado y el suelo, en el aislamiento acústico entre los recintos, es el de una capa amortiguadora, que hace que este tipo de suelo pueda considerarse como flotante.

Palabras clave: forjados; aislamiento acústico; suelos flotantes; arena; rehabilitación.

\section{ABSTRACT}

This work presents and analyses the experimental field results of the sound insulation from airborne and impact noise of the horizontal separating elements commonly used in the past, in which a uniform layer of sand was placed on top of the floor construction to serve as a base for the ceramic tiling.

The results of the acoustic measurements show that when there is an intermediate layer of sand in the horizontal separating element between rooms, the sound insulation is greater than would be obtained with other construction systems with equal mass per unit area, where the floor is joined rigidly to the floor construction. The effect on the sound insulation between the rooms produced by this layer of sand placed between the floor construction and the tiling is that of a cushioning layer, and demonstrates that this type of structure acts as a floating floor.

Keywords: floor constructions; sound insulation; floating floor; sand; restoration.

(*) Universidad Politécnica de Madrid (Madrid, España). 


\section{INTRODUCCIÓN}

Para que en los recintos haya unas condiciones de confort acústico adecuadas a su uso, en lo referente al aislamiento acústico es necesario conocer las propiedades acústicas de los diferentes sistemas constructivos. En particular, los elementos horizontales de separación entre recintos superpuestos tienen que cumplir unos requerimientos mínimos de aislamiento acústico a ruido aéreo y de nivel de ruido de impactos.

El elemento de separación horizontal entre recintos suele ser un sistema multicapa que consta de tres partes diferenciadas: el forjado o soporte base, varias capas intermedias con diferentes funciones colocadas sobre el forjado y finalmente el suelo. Las mayores exigencias de eficiencia energética y de confort térmico y acústico han obligado a desarrollar sistemas de recubrimientos más complejos (1). En los últimos años, en particular, se han desarrollado multitud de capas elásticas basadas en espumas poliméricas.

En la construcción del elemento de separación horizontal entre dos recintos, ha sido habitual el colocar sobre el forjado y solidarias a él, una capa de compresión o de reparto de cargas y otra de nivelación, encima una capa uniforme de arena de miga que sirve de asiento de la capa de agarre y el suelo cerámico. La arena de miga es un material de granulometría mayoritariamente arenosa, con un contenido de finos que no supera el $25 \%$, está compuesta de feldespatos, micas, esmécticas, cuarzo y caolinita; su densidad seca media es de aproximadamente $1.900 \mathrm{~kg} / \mathrm{m}^{3}$ (2). La capa de arena llega hasta las paredes del recinto, y no está adherida a ellas y al forjado. De esta forma, el suelo tradicional ha sido un suelo flotante, válido para situaciones con unas exigencias normales de resistencia mecánica.

Es conocido (3) que en el caso de forjados de vigas de madera se consigue una mejora importante del aislamiento a ruido aéreo colocando una capa de arena debajo del suelo. La arena seca se caracteriza por tener un factor de pérdidas internas elevado, $0,12 \leq \eta_{\text {int }} \leq 0,6(4,5)$ y un coeficiente de rigidez dinámica vertical de aproximadamente $\mathrm{s}^{\prime}=0,4 \mathrm{MN} / \mathrm{m}^{3}(6)$. Que el factor de pérdidas de un sistema constructivo sea elevado aumenta el valor de su índice de reducción acústica. El valor tan pequeño del coeficiente de rigidez dinámica de la arena hace que sea muy eficaz como capa intermedia elástica al realizar un suelo flotante. En este caso, la frecuencia de resonancia del suelo flotante es inferior al de las frecuencias de interés en la acústica de la edificación, cuyo rango está en las comprendidas en las bandas de tercio de octava de frecuencia central entre 100 $\mathrm{Hz}$ y $5 \mathrm{kHz}$. Valores bajos de la frecuencia de resonancia

\section{INTRODUCTION}

In order to ensure that each room has the appropriate conditions of acoustic comfort according to its use, it is necessary to know the sound insulation properties of the various construction systems. Specifically, the horizontal separating elements between rooms one above another must comply with the minimum requirements for airborne sound insulation and impact sound pressure level.

The horizontal separating element between rooms usually consists of a system of various layers with three different parts: the floor construction or base support, several intermediate layers with various functions placed on top of the floor construction, and finally the flooring itself. The increased requirements for energy efficiency and thermal comfort have made it necessary to develop more complex flooring systems (1). In recent years particularly, a wide variety of flexible layers have been developed based on polymer foams.

Until very recently, when building the horizontal separating element between two rooms it was common practice to place a compression layer for load distribution and another levelling layer on top -and forming part- of the floor construction element, followed by an even layer of sand which served as a base for the adhesive layer and the ceramic flooring. The sand used in these tests is a typical sand found in the subsoil of the city of Madrid, known as "arena de miga". This material has a mainly sandy granulometry with a fine content of not more than $25 \%$, and is composed of felspars, mica, smectites, quartz and kaolinite; its average dry density is approximately $1900 \mathrm{~kg} / \mathrm{m}^{3}$ (2). The sand layer extends up to the walls of the rooms and is not attached to the walls or to the floor construction. This traditional floor system forms a type of floating floor which is suitable for situations with normal requirements for mechanical resistance.

It is known (3) that in the case of floor constructions with wooden beams, airborne sound insulation can be considerably improved by placing a layer of sand under a floating floor. Dry sand is characterised by having a high internal loss factor, $0.12 \leq \eta_{\text {int }} \leq 0.6(4,5)$ and a coefficient of vertical dynamic stiffness per area unit of approximately $s^{\prime}=0.4 \mathrm{MN} / \mathrm{m}^{3}$ (6). The higher the loss factor of a construction system, the higher the value of its sound reduction index. The very low value of the dynamic stiffness coefficient of sand makes it very effective as an elastic intermediate layer when creating a floating floor. In this case, the resonance frequency of a floating floor is lower than that of the useful frequencies in building acoustics, whose range lies within one-third octave bands in the central frequency, between $100 \mathrm{~Hz}$ and $5 \mathrm{kHz}$. Low resonance frequency values in a floating floor increase the 
del suelo flotante producen un aumento del aislamiento acústico a ruido aéreo y una reducción del nivel de presión acústica de impactos del sistema $(7,8)$.

En este trabajo se exponen y se analizan los resultados experimentales in situ del aislamiento acústico a ruido aéreo y a ruido de impactos de elementos de separación horizontales que constan de forjados unidireccionales de semiviguetas pretensadas y bovedillas cerámicas con capa de compresión, o de forjado reticular recuperable. Sobre ellos está colocada una capa de arena y sobre esta una capa de agarre y el suelo de terrazo. Los recintos objeto de este trabajo tiene una dimensiones superiores a las habituales en los edificios de uso residencial, al ser aulas o laboratorios en edificios de enseñanza universitaria.

El objetivo principal de este trabajo es probar experimentalmente in situ, el efecto que la capa de arena colocada entre el forjado y el suelo tiene sobre el aislamiento acústico entre los recintos (ruido aéreo y ruido de impactos). Posteriormente, se comparan estos resultados con los obtenidos en otros sistemas constructivos con forjados semejantes pero sin capa de arena intermedia.

Las mediciones acústicas se han realizado en varios recintos superpuestos mediante aplicación de las normas EN ISO 140 - Partes 4, 7, 14; (9-12) y su valoración global según la norma EN ISO 717- Partes 1 y $2 ;(13,14)$.

Como magnitudes relevantes para expresar el aislamiento a ruido aéreo entre recintos se ha utilizado el índice de reducción acústica aparente $\mathrm{R}^{\prime}$, calculado de las mediciones acústicas de acuerdo con la fórmula [1]: sound insulation from airborne noise and reduce the impact sound pressure level of the system $(7,8)$.

This work presents and analyses the experimental field results of the sound insulation from airborne and impact noise of horizontal separating elements consisting of unidirectional floor constructions of pre-stressed beam and ceramic pot with a compression layer or with a recoverable reticular floor construction. A layer of sand is placed on top, followed by the adhesive layer and the terrazzo flooring. The rooms studied in this work are the classrooms and laboratories in buildings designed for university teaching, and therefore have larger dimensions than buildings for residential use.

The main objective of this work is to determine experimentally in the field the effect on the sound insulation between rooms (airborne and impact noise) of placing a layer of sand between the floor construction and the flooring. Subsequently, these results are compared to those obtained from other construction systems with a similar floor construction but without the intermediate sand layer.

For this study we have applied standards EN ISO 140 Parts 4, 7, 14 (9-12) and for single number rating EN ISO 717- Parts 1 and 2. $(13,14)$.

As a relevant quantity to express the airborne insulation between rooms we use the apparent sound reduction index $R^{\prime}$, determined from measurements according to [1]:

$$
R^{\prime}=L_{1}-L_{2}+10 \log \frac{S}{A} d B
$$

donde

where

$L_{1}$ y $L_{2}$ son los niveles de presión sonora promedios medidos en los recintos emisor y receptor respectivamente, en $\mathrm{dB}$. S es el área del elemento separador entre recintos, en $\mathrm{m}^{2}$ y $\mathrm{A}$ es el área de absorción acústica equivalente en el recinto receptor, en $\mathrm{m}^{2}$.

$L_{1}$ and $L_{2}$ are the average sound pressure levels measured in the source room and receiving room respectively, in $d B . S$ is the area of the separating element, in $m^{2}$, and $A$ is the measured equivalent sound absorption area in the receiving room, in $\mathrm{m}^{2}$.

In order to evaluate the impact sound insulation between rooms we use the normalized impact sound pressure level $L^{\prime}$, given by [2] pactos normalizado $L^{\prime}{ }_{n}$, obtenido de la expresión [2]

$$
L_{n}^{\prime}=L_{i}+10 \log \frac{A}{10 m^{2}} \quad d B
$$

donde

$L_{i}$ es el nivel de presión sonora de impactos en bandas de frecuencia, medido en el recinto receptor, en $\mathrm{dB}$, cuando el where

$L_{i}$ is the impact sound pressure level in frequency bands measured in the receiving room, in $d B$, when the floor 
suelo objeto de estudio está excitado por una máquina de impactos normalizada. A es el área de absorción acústica equivalente en el recinto receptor, en $\mathrm{m}^{2}$.

\section{LOS RECINTOS OBJETO DEL ESTUDIO}

Los recintos objetos de estudio han sido ocho aulas situadas en diferentes Escuelas o Facultades en la Ciudad Universitaria de Madrid. En las Tablas 1 y 2 se indican las dimensiones geométricas de los recintos estudiados, tipos de forjados, suelos y masa por unidad de superficie estimada de acuerdo con mediciones in situ de los espesores. El espesor de la capa intermedia de arena entre el forjado y el suelo varía entre 3 y $5 \mathrm{~cm}$. under study is excited by the normalized impact machine. $A$ is the measured equivalent sound absorption area in the receiving room, in $\mathrm{m}^{2}$.

\section{THE ROOMS IN THE STUDY}

The rooms which are the object of the study are eight classrooms located in various faculty buildings in the Ciudad Universitaria campus in Madrid. Tables 1 and 2 show the geometric dimensions of the rooms in the study, types of floor construction, flooring and estimated mass per unit area according to the field measurements of their thickness. The thickness of the intermediate sand layer between the floor construction and the flooring is between 3 and $5 \mathrm{~cm}$.

Tabla 1 / Table 1

Características del elemento horizontal de separación entre los recintos.

Characteristics of the horizontal separating elements between the rooms.

\begin{tabular}{|c|c|c|c|c|c|}
\hline $\begin{array}{l}\text { Escuela, Facultad / } \\
\text { School, Faculty }\end{array}$ & $\begin{array}{l}\text { Año de construcción } \\
\text { I Year of construction }\end{array}$ & $\begin{array}{l}\text { Tipo de forjado / } \\
\text { Type of floor } \\
\text { construction }\end{array}$ & $\begin{array}{c}\text { Masa por unidad de area del forjado / } \\
\text { Mass per unit area of floor } \\
\text { construction } \mathrm{kg} / \mathrm{m}^{2}\end{array}$ & $\begin{array}{l}\text { Suelo / } \\
\text { Flooring }\end{array}$ & $\begin{array}{c}\text { Masa total / } \\
\text { Total mass } \\
\mathrm{kg} / \mathrm{m}^{2}\end{array}$ \\
\hline $\begin{array}{l}\text { F. Periodismo / } \\
\text { Journalism Faculty }\end{array}$ & 1972 & $\begin{array}{l}\text { Reticular recuperable / } \\
\text { Recoverable reticular }\end{array}$ & 545 & $\begin{array}{l}\text { Baldosa de } \\
\text { terrazo / } \\
\text { terrazzo tile }\end{array}$ & 645 \\
\hline $\begin{array}{l}\text { E. I. Agrónomos / } \\
\text { Agricultural School }\end{array}$ & 1988 & $\begin{array}{c}\text { Semiviguetas } \\
\text { y bovedilla cerámica / } \\
\text { Beam and pot }\end{array}$ & 421 & $\begin{array}{c}\text { Baldosa de } \\
\text { terrazo / } \\
\text { terrazzo tile }\end{array}$ & 561 \\
\hline $\begin{array}{l}\text { E.I. Forestales / } \\
\text { Forestry School }\end{array}$ & 1994 & $\begin{array}{c}\text { Semiviguetas } \\
\text { y bovedilla cerámica / } \\
\text { Beam and pot }\end{array}$ & 574 & $\begin{array}{c}\text { Baldosa de } \\
\text { terrazo / } \\
\text { terrazzo tile }\end{array}$ & 674 \\
\hline $\begin{array}{c}\text { F. Químicas / } \\
\text { Chemistry Faculty }\end{array}$ & 2003 & $\begin{array}{c}\text { Semiviguetas } \\
\text { y bovedilla cerámica / } \\
\text { Beam and pot }\end{array}$ & 469 & $\begin{array}{c}\text { Baldosa de } \\
\text { terrazo / } \\
\text { terrazzo tile }\end{array}$ & 569 \\
\hline
\end{tabular}

Tabla 2 / Table 2

Datos geométricos de los recintos objeto de estudio acústico. Geometric data on the rooms in the acoustic study.

\begin{tabular}{|c|c|c|c|c|c|c|}
\hline $\begin{array}{c}\text { Ensayo / } \\
\text { Test }\end{array}$ & $\begin{array}{l}\text { Recintos I } \\
\text { Premises }\end{array}$ & $\begin{array}{l}\text { Longitud / } \\
\text { Length } \mathrm{m}\end{array}$ & $\begin{array}{l}\text { Anchura I } \\
\text { Width } m\end{array}$ & $\begin{array}{l}\text { Altura I } \\
\text { Height } m\end{array}$ & $\begin{array}{l}\text { Volumen I } \\
\text { Volume } \mathrm{m}^{3}\end{array}$ & $\begin{array}{l}\text { Área del suelo / } \\
\text { Area of separating floor, } m^{2}\end{array}$ \\
\hline \multirow{2}{*}{$\begin{array}{c}\text { F. Periodismo / } \\
\text { Journalism Faculty }\end{array}$} & Aula / Classroom 508 & 15.0 & 8.8 & 3.6 & 606.7 & \multirow{2}{*}{117.8} \\
\hline & Aula / Classroom 301 & 15.5 & 7.6 & 5.31 & 475.2 & \\
\hline \multirow{2}{*}{$\begin{array}{l}\text { E.I. Agrónomos / } \\
\text { Agricultural School }\end{array}$} & Aula / Classroom B33 & 13.53 & 10.31 & 2.83 & 395.1 & \multirow{2}{*}{139.6} \\
\hline & Aula / Classroom B24 & 13.53 & 10.31 & 2.83 & 395.1 & \\
\hline \multirow{2}{*}{$\begin{array}{l}\text { E.I. Forestales / } \\
\text { Forestry School }\end{array}$} & Aula / Classroom 7 & 10.25 & 7.05 & 3.3 & 234.1 & \multirow{2}{*}{71} \\
\hline & Dasometric lab. & 10.06 & 7.05 & 3.3 & 238.5 & \\
\hline \multirow{2}{*}{$\begin{array}{c}\text { F. Químicas / } \\
\text { Chemistry Faculty }\end{array}$} & Aula / Classroom QC22 & 15.43 & 10.03 & 2.9 & 448.8 & \multirow{2}{*}{156} \\
\hline & Aula / Classroom QC11 & 15.43 & 10.03 & 2.9 & 448.8 & \\
\hline
\end{tabular}

\section{RESULTADOS EXPERIMENTALES}

Los recintos en los que se han realizado los ensayos acústicos se utilizan como aulas y sus dimensiones geométricas son mayores que las de los recintos habituales en los edificios de uso residencial. Por ello en las mediciones acústicas del aislamiento a ruido aéreo se han realizado más tomas de datos de las habituales. Se han utilizado

\section{EXPERIMENTAL RESULTS}

The rooms in which the acoustic testing was carried out are used as classrooms, and their geometric dimensions are thus greater than normal rooms in residential buildings. For this reason a higher than usual amount of data were recorded for the acoustic measurements of airborne sound insulation. Three positions of sound source were 
tres posiciones de fuente sonora, quince posiciones para las medidas de $L_{1}$ y $L_{2}$, y 24 posiciones para la medida del tiempo de reverberación en el recinto receptor $T_{2}$. En la evaluación de los ruidos de impactos, para la máquina de impactos normalizada se han utilizado 8 posiciones. El tiempo de promediado de cada medida ha sido de 30 segundos.

En las Figuras 1 y 2 se muestran los resultados experimentales de las mediciones del índice de reducción acústica aparente $\mathrm{R}^{\prime}$ y del nivel de presión sonora de impactos normalizado $L_{n}^{\prime}$, en el rango de frecuencias de un tercio de octava entre $100 \mathrm{~Hz}$ y $5.000 \mathrm{~Hz}$, así como los valores globales ponderados de dichas magnitudes con sus términos de adaptación de espectros.

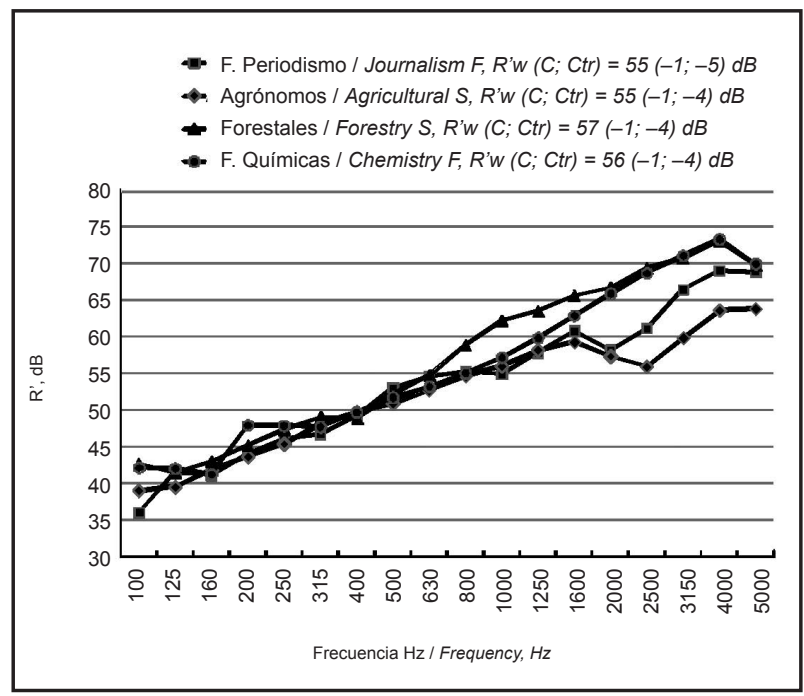

Figura 1. Índice de reducción acústica aparente $\mathrm{R}^{\prime}$ de los forjados analizados.

Figure 1. Apparent sound reduction index $R^{\prime}$ of the floor constructions analysed.

\section{ANÁLISIS DE LOS RESULTADOS OBTENIDOS}

\subsection{Aislamiento acústico a ruido aéreo}

Las mediciones acústicas del índice de reducción acústica aparente entre los recintos muestra que los valores índice de reducción acústica aparente $\mathrm{R}^{\prime}$ aumentan uniformemente en función de la frecuencia, hasta la banda de frecuencia central de $1.600 \mathrm{~Hz}$, a frecuencias superiores los valores tienen una mayor dispersión. Los índices ponderados de reducción acústica aparente $\mathrm{R}^{\prime}{ }_{\mathrm{w}}$ varían entre 55 y $57 \mathrm{~dB}$.

Una expresión teórica del índice de reducción acústica aparente $\mathrm{R}^{\prime}$, en función de la masa por unidad de superficie used, 15 positions for the measurements of $L_{1}$ and $L_{2}$, and 24 positions for the measurement of the reverberation time in the $T_{2}$ receiving room. Eight positions of the normalized impact machine were used for the evaluation of impact noise. The average time for each measurement was 30 seconds.

Figures 1 and 2 show the experimental results of the measurements of the apparent sound reduction index $R$ ' and the normalized impact sound pressure level $L_{n}^{\prime}$ in the frequency range between $100 \mathrm{~Hz}$ and $5000 \mathrm{~Hz}$, in addition to the weighted global values of these magnitudes with their spectral adaptation terms.

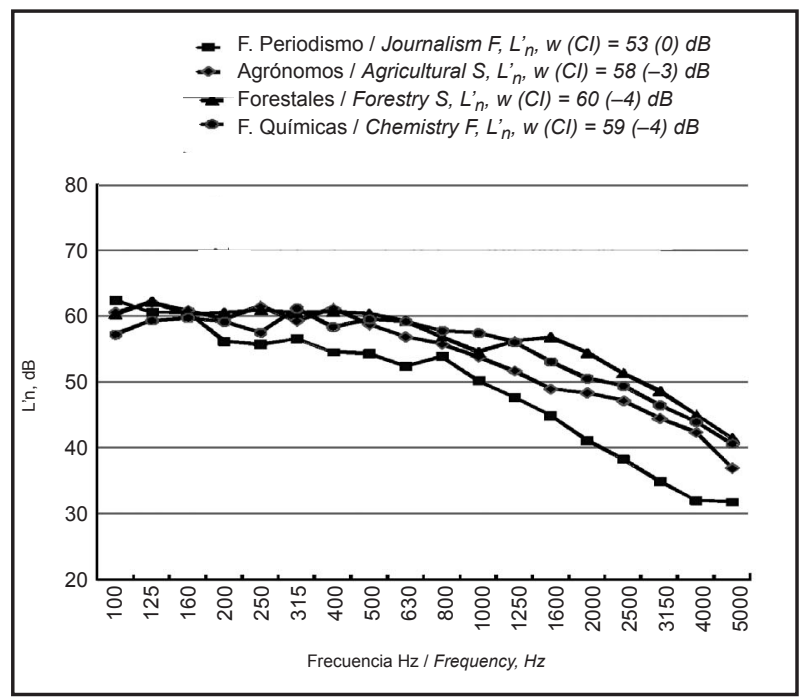

Figura 2. Nivel de presión sonora de impactos normalizado $L_{n}$ en los recintos objeto de ensayo.

Figure 2. Normalized impact sound pressure level $L_{n}$ in the rooms tested.

\section{ANALYSIS OF THE RESULTS OBTAINED}

\subsection{Airborne sound insulation}

The acoustic measurements of the apparent sound reduction index between the rooms show that the values for the apparent sound reduction rate $R^{\prime}$ increase uniformly as a function of the frequency, until the central frequency band of $1600 \mathrm{~Hz}$. At higher frequencies the values have a greater dispersion. The values of the apparent weighted sound reduction index $R^{\prime}{ }_{w}$ vary between 55 and $57 d B$.

The following theoretical expression of the apparent sound reduction index $R^{\prime}$, based on mass per unit area 
y la frecuencia, para este tipo de elementos horizontales de separación entre recintos, con capa de arena intermedia, que ajusta aceptablemente bien con los resultados experimentales obtenidos es la siguiente [3]: and frequency in this type of horizontal separating elements with an intermediate sand layer between rooms, acceptably fits the experimental results obtained [3]:

$$
R^{\prime}=15 \log \left(\frac{m^{\prime}}{1 \mathrm{~kg} / \mathrm{m}^{2}}\right)+20 \log (f / 1 \mathrm{~Hz})-44 \mathrm{~dB} ; \mathrm{m}^{\prime}>300 \mathrm{~kg} / \mathrm{m}^{2}
$$

En la Figura 3, se muestran los resultados experimentales y los calculados mediante la ecuación anterior para dos de los forjados
Figure 3 shows the experimental results and the result calculated using the equation above for two of the floor constructions.

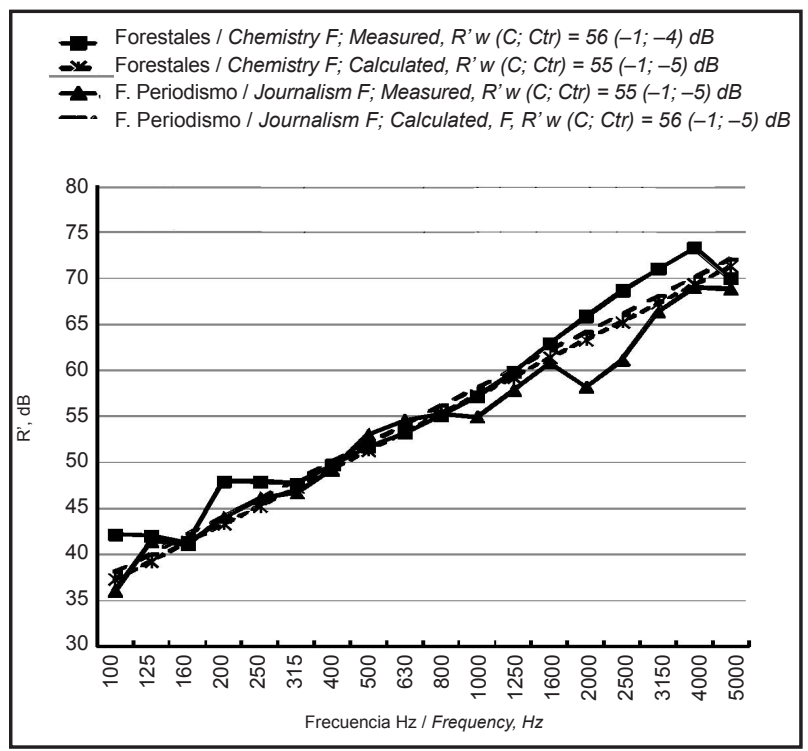

Figura 3. Comparación de los índices de reducción acústica aparentes medidos y calculados.

Figure 3. Comparison of measured and calculated apparent sound reduction index.

A continuación se realiza una comparación de los valores del índice ponderado de reducción acústica $\mathrm{R}^{\prime}{ }_{\mathrm{w}}$ de elementos horizontales de separación entre recintos, con capa de arena intermedia y sin ella. En el caso de recintos superpuestos en edificios de uso residencial, con forjados homogéneos unidireccionales de hormigón armado, con bovedilla cerámica y sin suelo amortiguador, los valores del índice ponderado de reducción acústica aparente in situ, para densidades de masa superficial del elemento horizontal de separación, $\mathrm{m}^{\prime}>300 \mathrm{~kg} / \mathrm{m}^{2}$, se pueden calcular mediante la ecuación siguiente [4] (15) :

$$
R_{w}^{\prime}=29+8 \log \left(\frac{m^{\prime}}{1 \mathrm{~kg} / \mathrm{m}^{2}}\right) \quad d B
$$
ecuación anterior tiene un rango de $\pm 3 \mathrm{~dB}$. A partir de la ecuación anterior se puede hacer una estimación del índice ponderado de reducción acústica aparente, considerando que la capa de arena y el suelo están unidos rígidamente al forjado. Los resultados se muestran en la Tabla 3.
La desviación típica de los valores obtenidos mediante la
In the case of rooms located one above another in buildings for residential use, with unidirectional homogeneous reinforced concrete floor constructions with a ceramic pot system and with no cushioning flooring, the values of the apparent weighted sound reduction index measured in the field for densities of mass per unit area of the horizontal separating element, $m^{\prime}>300 \mathrm{~kg} / \mathrm{m}^{2}$, can be calculated by means of the following equation (15) [4]:
The apparent weighted sound reduction index can be estimated by the above equation, in the case that the sand layer and the flooring are rigidly attached to the floor construction. The results are shown in Table 3. The intermediate layer of sand produces an improvement in the apparent weighted sound reduction index 
La existencia de la capa intermedia de arena produce una mejora del índice ponderado de reducción acústica aparente $R^{\prime}{ }_{w}$ que se puede estimar entre 4 y $5 \mathrm{~dB}$, respecto a considerar todo el sistema unido rígidamente.
$R^{\prime}{ }_{w}$ which is estimated at between 4 and $5 \mathrm{~dB}$, compared to the case when the whole system is rigidly attached.

Tabla 3 / Table 3

Índice de ponderado reducción acústica aparente del elemento horizontal medido y calculado supuesto monolítico. Apparent weighted sound reduction index of the horizontal element measured and calculated assuming a monolithic system.

\begin{tabular}{|c|c|c|c|}
\hline $\begin{array}{l}\text { Escuela, Facultad / } \\
\text { School, Faculty }\end{array}$ & $\begin{array}{c}\text { Medido in situ con capa de arena I } \\
\text { Measured in the field with dry sand layer } \\
R^{\prime} w, d B\end{array}$ & $\begin{array}{c}\text { Calculado sin capa de arena I } \\
\text { Calculated, without dry sand layer } \\
R^{\prime} w, d B\end{array}$ & $\Delta \mathbf{R}^{\prime} \mathbf{w}, \mathbf{d B}$ \\
\hline F. Periodismo / Journalism Faculty & 55 & 51 & 4 \\
\hline E.I. Agrónomos / Agricultural School & 55 & 51 & 4 \\
\hline E.I.Forestales / Forestry School & 57 & 52 & 5 \\
\hline F. Químicas / Chemistry Faculty & 56 & 51 & 5 \\
\hline
\end{tabular}

\subsection{Nivel de ruido de impactos}

Las mediciones acústicas del nivel de presión sonora de impactos normalizado $L_{n}^{\prime}$ de cada uno de los ensayos realizados, representados en la Figura 2 , indican que los forjados de vigueta con bovedilla cerámica tienen unas curvas parecidas en función de la frecuencia. Para el caso estudiado de un forjado reticular (CC de la Información), el nivel de presión sonora de impactos normalizado es inferior a los anteriores, en particular a altas frecuencias. Como en el apartado anterior, se realiza una comparación de los valores del nivel de presión acústica ponderado de impactos normalizado $L^{\prime}{ }_{n, w}$ de elementos horizontales de separación entre recintos, con capa de arena intermedia y sin ella.

Según la referencia (15), para forjados unidireccionales de hormigón armado y con bovedilla cerámica sin suelo amortiguador, el nivel de presión acústica ponderado de impactos normalizado in situ, para $\mathrm{m}^{\prime}>300 \mathrm{~kg} / \mathrm{m}^{2}$, se puede calcular a partir de la ecuación siguiente [5]:

\subsection{Impact sound insulation}

The acoustic measurements of the normalized impact sound pressure level $L_{n}^{\prime}$ for each of the tests carried out and shown in Figure 2 indicate that floor constructions with the beam and ceramic pot system have similar curves based on frequency. When the floor construction is reticular (Journalism Faculty), the normalized impact sound pressure level is lower than in the previous cases, particularly at high frequencies.

According to the reference (15), for unidirectional reinforced concrete floor constructions with ceramic pots and without any cushioning flooring, the weighted normalized impact sound pressure level in the field for rooms one above another, for $m^{\prime}>300 \mathrm{~kg} / \mathrm{m}^{2}$, can be calculated using the following equation [5]:

$$
L_{n, w}^{\prime}=115-15 \log \left(\frac{m^{\prime}}{1 \mathrm{~kg} / \mathrm{m}^{2}}\right) d B
$$

La desviación típica de los valores obtenidos mediante la ecuación anterior tiene un rango de $\pm 4 \mathrm{~dB}$. A partir de la ecuación anterior se puede hacer una estimación del nivel de presión acústica ponderado de impactos normalizado $L^{\prime}{ }_{n, w}$, considerando que la capa de arena y el suelo están unidos rígidamente al forjado. Los resultados se muestran en la Tabla 4. La existencia de la capa intermedia de arena produce una disminución del nivel de presión acústica ponderado de impactos normalizado $\Delta \mathrm{L}^{\prime}{ }_{\mathrm{n}}$,w , que se puede estimar entre 13 y $20 \mathrm{~dB}$ con respecto a la suposición de que todo el sistema está unido rígidamente.
Based on the equation above, an estimation can be made of the weighted normalized impact sound pressure level $L_{n, w}^{\prime}$ considering the case that the layer of sand and the flooring are rigidly attached to the floor construction. The results are shown in Table 4. The intermediate sand layer produces a weighted reduction of the impact sound pressure level $\Delta L_{n \prime}^{\prime}{ }_{n,}$ of between 13 and $20 \mathrm{~dB}$, assuming the case that the whole system is rigidly attached. 
Tabla 4 / Table 4

Nivel de presión acústica ponderado de impactos normalizado $L^{\prime}{ }_{n}$ W del elemento horizontal medido y calculado supuesto homogéneo. Weighted normalized impact sound pressure level $L^{\prime}{ }_{n}, w$ of the horizontal element measured and calculated assuming the case of a homogeneous system.

\begin{tabular}{|c|c|c|c|}
\hline $\begin{array}{c}\text { Escuela, Facultad / } \\
\text { School, Faculty }\end{array}$ & $\begin{array}{c}\text { Medido in situ con capa de arena I } \\
\text { Measured in the field with dry sand layer } \\
\qquad L^{\prime} n, w, d B\end{array}$ & $\begin{array}{c}\text { Calculado sin capa de arena I } \\
\text { Calculated, without dry sand } \\
\text { layer } L ' n, w, d B\end{array}$ & $\begin{array}{c}\text { Reducción / } \\
\text { Reduction } \Delta L^{\prime} n, w d B\end{array}$ \\
\hline F. Periodismo / Journalism Faculty & 53 & 73 & 20 \\
\hline E.I.Agrónomos / Agricultural School & 58 & 74 & 16 \\
\hline E.I. Forestales / Forestry School & 60 & 73 & 13 \\
\hline F. Químicas / Chemistry Faculty & 59 & 74 & 15 \\
\hline
\end{tabular}

\section{3. ¿Existe una relación entre el índice de reducción acústica aparente y el nivel de presión sonora de impactos normalizado para este tipo de elementos horizontales de separación?}

Para sistemas constructivos homogéneos los aislamientos acústicos a ruido aéreo y a ruido de impactos están relacionados mediante una ley de reciprocidad, de forma que la suma del índice de reducción acústica y el nivel de presión sonora de impacto normalizado depende únicamente de la frecuencia, si las transmisiones forzadas no se tienen en consideración $(16,17)$. En laboratorio, la relación de reciprocidad en bandas de frecuencia de tercio de octava sigue la expresión [6]:

$$
R+L_{n}=43+30 \lg \frac{f}{(1 H z)} \quad d B
$$

donde $\mathrm{f}$ es la frecuencia central de la banda de tercio de octava en Hercios.

Un valor global ponderado se puede deducir de la ecuación 6; [7] (18): [6], (18) [7]:

\subsection{Is there a relationship between the apparent sound reduction index and the normalized impact sound pressure level for this type of horizontal separating elements?}

For homogeneous building elements, airborne and impact sound insulation are related through the reciprocity relation, and the sum of the airborne sound reduction index and the normalized impact sound pressure level for homogeneous floor constructions depends only on frequency, if forced transmissions are ignored $(16,17)$. In the laboratory, based on data obtained in octave bands, the expression is [6]:

where $f$ is the octave band centre frequency in Hertz.

A global weighted value can be deduced from equation

$$
R_{w}+L_{n, w}=126 \pm 2 d B
$$

En el caso de suelos flotantes no hay una relación de reciprocidad entre índice de reducción acústica y el nivel de presión sonora de impacto normalizado.

En ensayos realizados in situ en el caso de forjados con vigas de hormigón y bovedillas cerámicas con un suelo de terrazo o parquet (15), existe una relación de reciprocidad experimental cuya ecuación es [8]:
In the case of floating floors there is no reciprocity relation between the sound reduction index and the normalized impact sound pressure level.

In field testing of floor constructions with a system of concrete beams and ceramic pots with a finishing of terrazzo or parquet (15), there is an experimental reciprocity relation whose equation is [8]:

$$
R^{\prime}+L_{n}^{\prime}=66+20 \log \left(\frac{f}{1 H z}\right) d B
$$

En la Figura 4 se representan las sumas de los índices de reducción acústica aparente y el nivel de presión sonora de impacto normalizado. Se observa que a partir de las frecuencias medias hay una gran dispersión de los datos
Figure 4 shows the sums of the apparent sound reduction index and the normalized impact sound pressure level. It can be observed from the mid-frequency range that there is a wide dispersion of data in the various tests. This 
en los diferentes ensayos. Esto muestra que no se cumple una relación de reciprocidad entre las magnitudes medidas. En la Figura 5 se puede ver la diferencia que existe entre la suma de los valores medidos de $R^{\prime}+L^{\prime} n$ y los calculados para forjados homogéneos in situ según la ley de reciprocidad, ecuación [8].

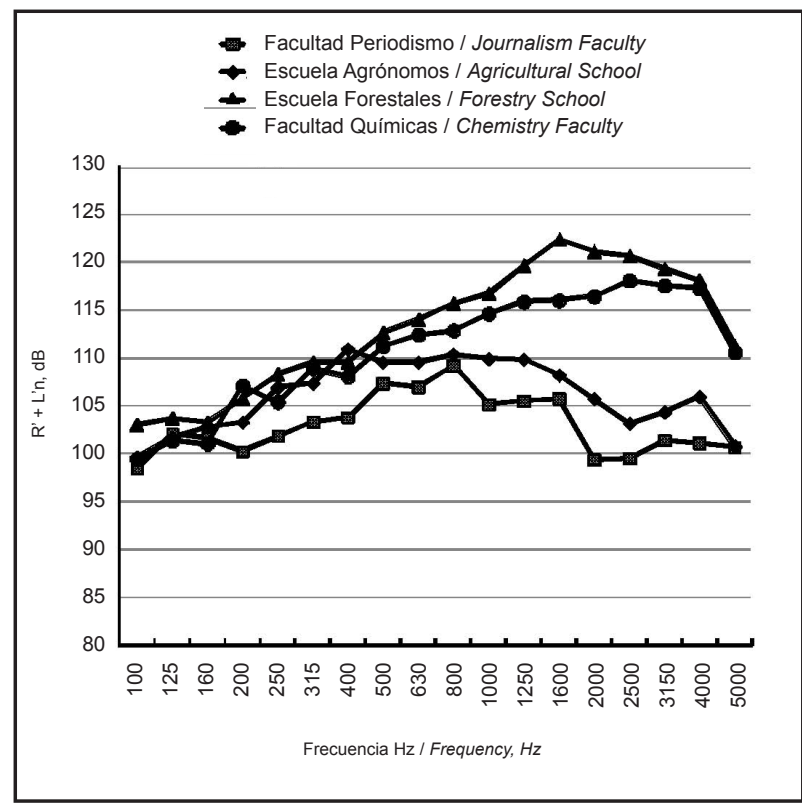

Figura 4. Suma de los valores medidos de $R^{\prime}+L^{\prime} n$ en los recintos objeto de ensayo.

Figure 4. Sum of the values measured for $R^{\prime}+L^{\prime} n$ in the rooms tested.

\section{CONCLUSIONES}

Se han realizado mediciones in situ del aislamiento acústico a ruido aéreo y del nivel de ruido de impactos entre recintos superpuestos. El elemento de separación horizontal entre los recintos consta de un forjado sobre el que se coloca una capa uniforme de arena de miga que sirve de asiento al suelo cerámico. Las áreas de las superficies de separación entre los recintos estudiados son mayores que las habituales en edificios de uso residencial.

Los resultados experimentales de las mediciones acústicas muestran que, cuando en el elemento de separación horizontal hay una capa intermedia de arena, el aislamiento acústico es mejor que el que se obtendría con otros sistemas constructivos con forjados semejantes, de igual masa por unidad de superficie, pero con todas las capas unidas rígidamente.

En el aislamiento acústico entre los recintos, el efecto de la capa de arena colocada entre el forjado y el suelo, es demonstrates that the reciprocity relation is not fulfilled between the magnitudes measured. Figure 5 shows the difference between the sum of the measured values of $R^{\prime}+L ' n$ and the values calculated in the field for homogeneous floor constructions according to the reciprocity law equation [8].

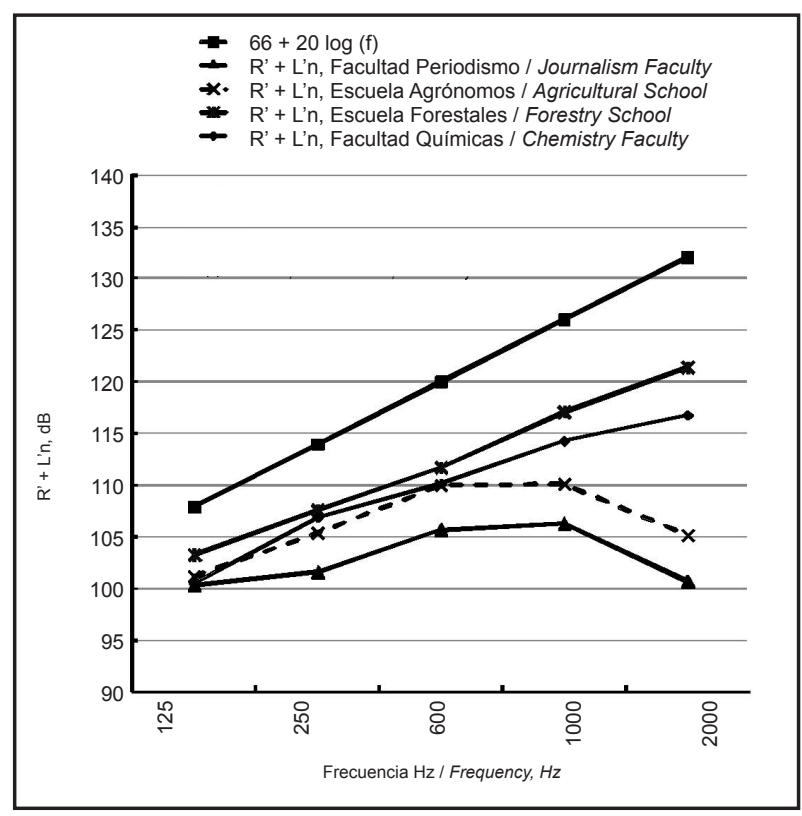

Figura 5. Comparación entre la suma de los valores medidos de $R^{\prime}+L^{\prime} n$ y los calculados para forjados homogéneos in situ según la ley de reciprocidad.

Figure 5. Comparison between the sum of the values measured for $R^{\prime}+L^{\prime} n$ and the values calculated in the field for homogeneous floor constructions according to the reciprocity law.

\section{CONCLUSIONS}

Field measurements were taken of the sound insulation from airborne noise and the impact noise level between rooms one above another. The horizontal separating element between the rooms is a type of construction system which was commonly used in the past. The slabs are placed on a bed of mortar, which is in turn supported by a layer of sand distributed evenly over the support system. The area of the separating elements between the rooms studied is greater than usual for residential buildings.

The experimental results of the sound measurements show that when there is an intermediate layer of sand in a horizontal separating element, the sound insulation is greater than that obtained with other construction systems with similar floor construction elements, with the same mass per unit area, but with all the layers rigidly joined together.

The effect on the sound insulation between the rooms produced by this layer of sand placed between the floor 
el de una capa amortiguadora, que hace que este suelo tradicional pueda considerarse como flotante.

Desde la perspectiva del aislamiento acústico entre recintos, la existencia de la capa intermedia de arena produce una mejora del índice de reducción acústica aparente $\mathrm{R}^{\prime}{ }_{\mathrm{w}}$ que se puede estimar entre 4 y $5 \mathrm{~dB}$ y una disminución del nivel normalizado de presión sonora de impactos normalizado $\Delta \mathrm{L}^{\prime}{ }_{\mathrm{n}, \mathrm{w}}$ estimada entre 13 y $20 \mathrm{~dB}$. Se ha obtenido una expresión teórica del índice de reducción acústica aparente $\mathrm{R}^{\prime}$ en función de la masa por unidad de superficie y la frecuencia para este tipo de elementos horizontales de separación entre recintos, con capa de arena intermedia, ecuación [3].

No hay una relación experimental de reciprocidad para la suma de los valores del índice de reducción acústica aparente y el nivel de presión sonora de impactos normalizado. construction and the flooring is that of a cushioning layer, and demonstrates that this type of structure acts as a floating floor.

From the standpoint of sound insulation between rooms, the intermediate layer of sand produces an improvement in the apparent sound reduction index $R^{\prime}{ }_{w}$ which can be estimated at between 4 and $5 \mathrm{~dB}$, and a decrease in the normalized impact sound pressure level $\Delta L_{n, w}^{\prime}$ of between 13 and $20 \mathrm{~dB}$. A theoretical expression of apparent sound reduction index $R^{\prime}$ was obtained based on mass per unit area and frequency for this type of horizontal separating element between rooms with an intermediate layer of sand.

There is no experimental reciprocity relation for the sum of the values of the apparent sound reduction index and the normalized impact sound pressure level.

\section{BIBLIOGRAFÍA / BIBLIOGRAPHY}

(1) CEN/TR 13548:2004. Rules for design and installation of ceramic tiling.

(2) Manzanal D.G.: Modelo constitutivo basado en la teoría de la plasticidad generalizada con la incorporación de parámetros de estado para arenas saturadas y no saturadas. Tesis Doctoral, E.T.S. de I de Caminos, Canales y Puertos, UPM (2008).

(3) Schmitt, H.; Heene, A.: Hochbaukonstruktion (12th edition), Friedr. Vieweg\&Sohn Verlagsgesellschaft mbH, Braunschweig (1993). http:// dx.doi.org/10.1007/978-3-322-85719-4

(4) Beranek, L.: Noise and Vibration Control, McGraw-Hill Inc (1971).

(5) Ungar, E.E.: Structural Damping. Ver L.I. and Beranek, L. (Eds.), Noise and Vibration Control Engineering, Wiley, N York (2006).

(6) Barkan, D.D.: Dynamics of Bases and Foundations, Ed. McGraw-Hill (1962).

(7) EN 12354 - 1: 2000, Building Acoustics, Estimation of acoustic performance of buildings from the performance of elements, Part 1: Airborne sound insulation between rooms, Brussels.

(8) EN 12354 - 2: 2000, Building Acoustics, Estimation of acoustic performance of buildings from the performance of elements, Part 2: Impact sound insulation between rooms, Brussels.

(9) EN ISO 140-4, Acoustics- Measurement of sound insulation in buildings and of building elements- Part 4: Field measurements of airborne sound insulation between rooms (ISO 140-4: 1998).

(10) EN ISO 140-7, Acoustics- Measurement of sound insulation in buildings and of building elements- Part 7: Field measurements of impact insulation of floors. (ISO 140-7:1998).

(11) UNE EN ISO 140-14:2005. Acoustics- Measurement of sound insulation in buildings and of building elements- Part 14: Guidelines for special situations in the field.(ISO 140-14:2004).

(12) UNE EN ISO 140-14:2005/AC: 2009. Acoustics- Measurement of sound insulation in buildings and of building elements- Part 14: Guidelines for special situations in the field.(ISO 140-14:2004/Cor 1:2007).

(13) EN ISO 717-1, Acoustics - Rating of sound insulation in buildings and of building elements. Part 1: Airborne sound insulation (ISO 717-1:1996). EN ISO 717-1. Amended 1: Rounding rules related to single number ratings and single number quantities. 2006. (ISO 7171:1996/AM1:2006).

(14) EN ISO 717-2: 1996, Acoustics - Rating of sound insulation in buildings and of building elements. Part 2: Impact sound insulation (ISO 717-2:1996). EN ISO 717-2: Amended 1:2006 (ISO 717-2:1996/AM 1:2006).

(15) Díaz, C.; Pedrero, A.: "Field measurements of Airborne and Impact Sound Insulation Between Rooms, One on Top of the Other, with Beam and Pot Floor Structures", Acta Acustica United with Acustica, vol. 90 (2004), 982-986.

(16) (16) Heckl, M.; Rathe, E.J.: "Relationship between the transmission loss and the impact noise insulation of floor structures" JASA 1963, 35: $1825-1830$

(17) Cremer, L.; Heckl, M.: Structure Borne Sound, 2nd edition, Berlin, Springer Verlag (1988).

(18) Gerretsen E.: "Calculation of airborne and sound insulation between dwellings", Applied Acoustics .1985, 19: 245-264. http://dx.doi. org/10.1016/0003-682X(86)90001-0 